
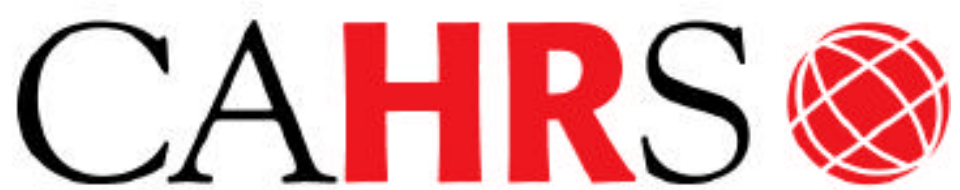

Center for Advanced Human Resource Studies
CAHRS / Cornell University 187 Ives Hall

Ithaca, NY 14853-3901 USA

Tel. 607 255-9358

www.ilr.cornell.edu/CAHRS/

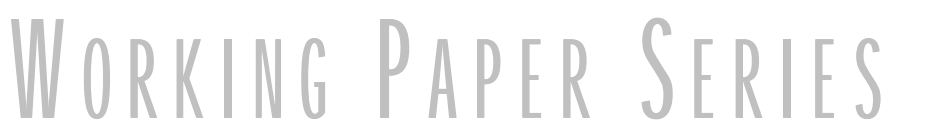

\title{
A Theoretical Exploration of the Adoption and Design of Flexible Benefit Plans: A Case of Human Resource Innovation
}

Melissa W. Barringer

George T. Milkovich

Working Paper 97 - 22 


\title{
A THEORETICAL EXPLORATION OF THE ADOPTION AND DESIGN OF FLEXIBLE BENEFIT PLANS: A CASE OF HUMAN RESOURCE INNOVATION
}

\author{
MELISSA W. BARRINGER \\ University of Massachusetts \\ Isenberg School of Management \\ Amherst, MA 01003 \\ PHONE: (413) 545-5628 \\ FAX: (413) 545-3858 \\ E-MAIL: mwb@mgmt.umass.edu \\ GEORGE T. MILKOVICH \\ Center for Advanced Human Resource Studies \\ ILR School/Cornell University \\ Ithaca, NY 14853-3901 \\ PHONE: (607) 255-4470 \\ FAX: (607) 257-6639 \\ E-MAIL: gtm1@cornell.edu \\ and \\ Hong Kong University of Science and Technology \\ Management of Organizations Department
}

Working Paper \#97-22

http://www.ilr.cornell.edu/cahrs

\begin{abstract}
We thank Anurag Sharma, Tony Butterfield, Pamela Tolbert, Madan Pilitula, Ken Smith (Editor), and three of this journal's anonymous reviewers for their invaluable comments on earlier drafts of this article.
\end{abstract}




\title{
A THEORETICAL EXPLORATION OF THE ADOPTION AND DESIGN OF FLEXIBLE BENEFIT PLANS: A CASE OF HUMAN RESOURCE INNOVATION
}

\begin{abstract}
This article explores theoretical explanations of managers' decisions about flexible benefit plans. We (1) examine the adoption and design of flexible benefit plans through four theoretic lenses: institutional, resource dependence, agency, and transaction costs; (2) integrate the relevant insights gained from these theories into a more complete model and derive propositions for future research; and (3) generalize the insights gained from exploring a specific innovation to broader questions surrounding decisions about other human resource innovations.
\end{abstract}


In the early 1970s, only a handful of companies offered flexible benefit plans. Today it is estimated that one-third of organizations with more than 1,000 employees offer flexible benefits (Hewitt, 1995). The early plans were relatively simple, offering few choices and limited flexibility. Current approaches range from simply offering pretax salary reductions to pay for benefits, to highly complex plans that offer many options.

Beyond surveys of firm practices, these developments have received little scholarly attention. Very little research has been addressed to understanding why some firms adopt and others do not, or why some plans offer more choices than others. Virtually nothing is known about why the variety of these plans has increased over time. What objectives are achieved? How do employees' attitudes, competitors' practices, rising benefit costs and shifting regulatory conditions affect management's decisions? ${ }^{1}$

Our purpose is to explore the insights offered by organization theories and research. Specifically, we (1) examine management's adoption and design decisions through four theoretic lenses: institutional, resource dependence, agency, and transaction costs; (2) integrate the insights gained from these theories and related research into a more complete model, with testable propositions for future empirical work; and (3) generalize these insights to other human resource innovations.

The principal contributions of our article are threefold: First, by integrating the insights of multiple theoretical perspectives, we offer a more parsimonious model of management's decisions about flexible benefits and a set of testable propositions that can guide much-needed research. None of the four theories considered here includes the full set of variables that may affect management's decisions about employee benefits. Each theory offers unique insights, however there is also some overlap. Second, our model and analysis offer a platform for understanding why organizations adopt other HR innovations. Finally, we bring together a diverse body of literature on flexible benefit plans around theoretic perspectives. Currently, the literature is largely segmented into benefits administration, survey evidence, and academic research.

To accomplish the article's three objectives, we first describe flexible benefit plans and review the related literature and research. Next, we present a brief overview of the four theories and highlight their relevance to flexible benefits decisions. Following this overview, we offer our integrated model based on specific insights gained from these theories and derive testable propositions. We conclude by discussing the potential to generalize our ideas to other human resource innovations. 


\section{FLEXIBLE BENEFIT PLANS}

\section{Flexible Benefit Plans Defined}

Definitions of benefits vary considerably. The narrowest definition includes only those benefits not underwritten or paid for by the government, such as health insurance or private pensions (Beam \& McFadden, 1996). Broader definitions include "virtually any form of compensation other than direct wages paid to employees" (Rosenbloom, 1996: 3) and encompass benefits that range from commonly observed retirement and insurance plans to unique offerings such as spiritual counseling or fruit from the orchard (Employee Benefit Research Institute, 1995).

Definitions of flexible benefit plans are less ambiguous, and the list of forms that are included in such plans more narrow. In general, any plan that allows employees to make choices about the benefits that they receive is considered to be a flexible benefit, or cafeteria, plan (Beam \& McFadden, 1996; Rosenbloom, 1996). For the purposes of this article, we use the definition set out in Section 125 of the Internal Revenue Code. Specifically, we define flexible benefit plans as those that offer employees a choice between qualified (nontaxable) benefits and cash (Beam \& McFadden, 1996). A plan that does not offer a cash option, for example a plan that simply offers a choice of medical plans, would not be considered a flexible benefit plan under this definition, whereas a plan that offers the option of paying for a (qualified, nontaxable) benefit with pre-tax wages (cash) would (Borleis, 1996).

Although the options that can be included in a flexible benefit plan are somewhat limited, the plans incorporate a variety of different designs, ranging in the amount of flexibility (choice) and the costs to the employer. We include four general types of designs that are consistent with the IRS definition adopted for use in this article: salary-reduction-only, modular options, core plus options, and mix and match. The four plan designs are summarized in Table 1 (Employee Benefit Research Institute, 1991; Beam \& McFadden, 1996). As the table shows, costs to the employer increase as the amount of flexibility increases (Beam \& McFadden, 1996). Hence, costs and flexibility are lowest under the "salary-reduction-only" design and highest under "mix and match." 


\section{TABLE 1: Flexible Benefit Plans}

\begin{tabular}{|c|c|}
\hline $\begin{array}{l}\text { Low flexibility } \\
\leftarrow\end{array}$ & \\
\hline Low cost & \\
\hline Salary-reduction-only & Modular Options \\
\hline $\begin{array}{l}\text { Premium conversion: } \\
\text { Employee pays premium for } \\
\text { insurance with pre-tax salary } \\
\text { reduction } \\
\text { Flexible spending account: }\end{array}$ & $\begin{array}{l}\text { Choice between several } \\
\text { different combinations of } \\
\text { benefits (usually same types } \\
\text { of benefits but different levels } \\
\text { of benefits) }\end{array}$ \\
\hline
\end{tabular}

Pre-tax salary reduction fund an account for paying uncovered medical or dependent care bills

\author{
Core + Optional Coverage \\ Core: Basic coverage in \\ certain areas (e.g., health, life \\ and/or disability insurance) \\ Plus: Flexible credits to \\ purchase additional coverage \\ in core area or in \\ supplemental areas such as \\ child care, vacation days, or \\ trade in for cash
}

High flexibility

High cost

\section{Mix \& Match}

Flexible credits are provided, and employee can purchase any type and level of coverage offered

Notes:

Flexible spending accounts (FSAs) may be included in any of the plans described above.

Medical plan options may include multiple types (HMOs, fee-for-service) and levels (e.g., high/medium/low deductible and coinsurance rates), or they may be limited to a choice between a single fee-for-service plan and an HMO.

\section{The Appeal of Flexible Benefit Plans}

Flexible benefit plans represent a substantial departure from a traditional, one-size-fits-all philosophy, where managers made decisions about the type and level of benefits employees would receive and all employees were covered by the same benefits. First introduced in the early 1970s, this innovative practice did not start to gain popularity until the mid-1980s (Hewitt, 1995). The number of adoptions increased by 127\% between 1983 and 1984, and has continued to increase steadily, although the rate has slowed since 1989. Currently, about $70 \%$ of firms that offer flexible benefit plans are in the service industry (Hewitt, 1995). The simpler, low flexibility type of design (salary-reduction-only) seems to be the most widely used, although the incidence of the highly flexible plans seems to be increasing (Hewitt, 1995; Employee Benefit Research Institute, 1995).

Managers most frequently cite two objectives in their decisions to adopt flexible benefit plans: (1) to enhance their employees' benefits satisfaction; or (2) to help contain rising benefits costs (Employee Benefit Research Institute, 1995). The premise underlying the first objective is that as the diversity of the workforce has increased, so too has the diversity of employees' benefits needs. Allowing employees to select a package that meets their individual needs has increasing appeal. In addition, flexible benefit plans hold the promise of containing costs by moving from a defined benefit (in which a certain package of benefits is promised, regardless of cost) to a defined contribution (in which a certain level of benefits expenditures is promised, regardless of what the 
funds can purchase) (Employee Benefit Research Institute, 1991). Further, by increasing choices and skillfully pricing the options, organizations could encourage employees to select more costeffective benefit forms (Barringer \& Mitchell, 1994; Barringer \& Milkovich, 1996; Borleis, 1996).

The benefits management literature attributes the impetus for adopting flexible benefit plans to cost pressures and the increasing diversity of the workforce as well, but also cites changing tax regulations (Borleis, 1996; Beam \& McFadden, 1996). Section 125 of the Internal Revenue Code, for example, permitted the use of flexible spending accounts to pay for medical or dependent care expenses, and eliminated the tax penalties for plans offering both taxable and non-taxable benefits.

The merits of flexible benefit plans are also espoused in the academic literature. Over twenty-five years ago, Lawler wrote that by heightening employees' awareness of benefit costs and ensuring that they receive the benefits they want, flexible benefit plans increase the perceived value of their pay. Drawing upon expectancy theory, he argued that flexible plans should reduce turnover and enhance attraction, because they increase the perceived value to employees of working for organizations that offered the plans (Lawler, 1971). More recently, he argued that the workforce has been changing in a number of ways (e.g., increasing diversity, less acceptance of traditional authority, changing family structures) that make flexible plans attractive to a substantial portion of employees and "potentially effective in most organizations" (Lawler, 1981: 76)

If carried to its logical conclusion, the satisfaction premise implies that organizations whose success is tied to their capacity to attract and retain qualified employees would have a strong reason to adopt flexible benefit plans. Yet few researchers have examined this basic premise. We found only three studies that directly analyze the effects of flexible benefits on employee attitudes and behaviors. Two -- case studies of single firms -- found that the adoption of flexible benefit plans was related to improved job satisfaction and lowered intentions to leave (Barber, et al., 1992; Heshizer, 1994). A third study examined the pay system preferences of graduating college students and found that an organization's attractiveness was significantly related to the presence of flexible benefits (Cable \& Judge, 1994).

\section{Explaining Variation in Decisions about the Adoption and Design of Flexible Benefit Plans}

The high costs of plan design and implementation, ever-changing regulations, paternalistic concerns about employees' capacity to make sound decisions, and actuarial concerns about disproportionate participation rates among options (adverse selection) have been offered as reasons why more organizations have not implemented flexible benefits (Bloom \& Trahan, 1986; Beam \& McFadden, 1996). That some organizations are deterred by these obstacles and others are not suggests that decisions about the plans are also affected by contextual factors. 
To better understand these factors, we turn next to explore the insights offered by organizational theories. We selected four theories: institutional, resource dependence, agency, and transaction cost. Our selections were based on two related criteria. First, we consider benefit plans to be attributes of organizations, akin to other organization processes and structures such as information systems, organization design, or hierarchical arrangements. The organization is the basic unit of analysis. Consequently, we did not include theories such as expectancy and procedural justice, because they tend to focus on the individual as the unit of analysis. Agency theory also focuses on individuals, however the unit of analysis is the contract between principals and agents (Eisenhardt, 1989). Second, we selected theories that have already been useful in offering explanations of other pay and benefits practices. Eisenhardt (1988) found that both the agency and institutional models partially described variation in the pay policies for salespersons at retail stores. Similarly, Pfeffer and Davis-Blake (1987) showed that the resource dependence perspective helped explain variation in the wages paid to university administrators. Goodstein (1994), and Ingram and Simons (1995), applied the resource dependence and institutional models to explain organizations' work-family practices. Williamson (1981) suggested that management's decisions about pensions may be related to transaction costs.

\section{CURRENT ORGANIZATIONAL THEORY: A REVIEW AND COMPARISON}

In this section we describe and analyze the four relevant theories. The results are summarized in Table 2, which contrasts the basic premises, key assumptions, implications and limitations of the institutional, resource dependence, agency and transaction models. Based on this analysis, we then derive a model that integrates the insights gained. 
TABLE 2: Theoretical Premises and Implications for Flexible Benefit Plans

\begin{tabular}{|c|c|c|c|c|}
\hline & Institutional & $\begin{array}{c}\text { Resource } \\
\text { Dependence }\end{array}$ & Agency & Transaction Cost \\
\hline Basic Premise & $\begin{array}{l}\text { Organizational structures are } \\
\text { shaped by institutional } \\
\text { environments. }\end{array}$ & $\begin{array}{l}\text { Organizational } \\
\text { structures are shaped } \\
\text { by agents who control } \\
\text { critical resources. }\end{array}$ & $\begin{array}{l}\text { Organizational } \\
\text { structures are } \\
\text { established to manage } \\
\text { agency problems. }\end{array}$ & $\begin{array}{l}\text { Organizational structures } \\
\text { are established to } \\
\text { minimize transaction } \\
\text { costs. }\end{array}$ \\
\hline Key Assumptions & $\begin{array}{l}\text { Legitimacy is paramount. } \\
\text { External pressures constrain } \\
\text { decisions. } \\
\text { Organizations do not exercise } \\
\text { active choice. }\end{array}$ & $\begin{array}{l}\text { Resource acquisition is } \\
\text { paramount. } \\
\text { External and/or internal } \\
\text { agents constrain } \\
\text { decisions. } \\
\text { Organizations exercise } \\
\text { active choice. }\end{array}$ & $\begin{array}{l}\text { Efficiency is } \\
\text { paramount. } \\
\text { Information } \\
\text { asymmetries and } \\
\text { partial goal conflict } \\
\text { constrain decisions. } \\
\text { Organizations exercise } \\
\text { active choice. } \\
\text { Agents are risk-averse } \\
\text { and self-interested. }\end{array}$ & $\begin{array}{l}\text { Efficiency is paramount. } \\
\text { Information asymmetries, } \\
\text { partial goal conflict, and } \\
\text { asset specificity constrain } \\
\text { decisions. } \\
\text { Organizations exercise } \\
\text { active choice. } \\
\text { Some people have a } \\
\text { propensity to behave } \\
\text { opportunistically. }\end{array}$ \\
\hline Key Predictors & $\begin{array}{l}\text { Early: Benefits objectives, } \\
\text { employee preferences, cost of } \\
\text { current (non-flex) benefits, } \\
\text { flexible plan costs } \\
\text { Late: Competitors' practices, } \\
\text { union density, legislation, } \\
\text { uncertainty, } \\
\text { interconnectedness }\end{array}$ & $\begin{array}{l}\text { Extent of unionization } \\
\text { in external labor } \\
\text { markets. } \\
\text { Dependence on critical } \\
\text { employees. }\end{array}$ & $\begin{array}{l}\text { Outcome uncertainty. } \\
\text { Observability and } \\
\text { measurability of } \\
\text { performance. }\end{array}$ & $\begin{array}{l}\text { Human asset specificity. } \\
\text { Observability and } \\
\text { measurability of } \\
\text { performance. }\end{array}$ \\
\hline $\begin{array}{l}\text { Major } \\
\text { Predictions: } \\
\text { Organizations } \\
\text { Most Likely to } \\
\text { Adopt Flex Plans }\end{array}$ & $\begin{array}{l}\text { Early: Employees value } \\
\text { choice, costs of current } \\
\text { (non-flex) benefits are high, } \\
\text { or costs of flexible plan } \\
\text { implementation are } \\
\text { affordable. } \\
\text { Late: Current legislation } \\
\text { favors flexibility. Union } \\
\text { density is low. Flexible } \\
\text { plans are prevalent in the } \\
\text { industry and uncertainty or } \\
\text { interconnectedness is high. }\end{array}$ & $\begin{array}{l}\text { Labor market is highly } \\
\text { unionized. Employees } \\
\text { are non-unionized, } \\
\text { have a high degree of } \\
\text { control over critical } \\
\text { resources and value } \\
\text { benefit flexibility. }\end{array}$ & $\begin{array}{l}\text { Outcome uncertainty is } \\
\text { high, monitoring } \\
\text { productivity is difficult } \\
\text { (monitoring costs are } \\
\text { high), and employees } \\
\text { value benefit flexibility. }\end{array}$ & $\begin{array}{l}\text { Critical skills are } \\
\text { organization-specific, } \\
\text { productivity is difficulty to } \\
\text { monitor, and employees } \\
\text { value benefit flexibility. }\end{array}$ \\
\hline $\begin{array}{l}\text { Major } \\
\text { Predictions: } \\
\text { Organizations } \\
\text { Most Likely to } \\
\text { Design Highly } \\
\text { Flexible Plans }\end{array}$ & $\begin{array}{l}\text { Early: Flexible plan } \\
\text { objectives emphasize } \\
\text { benefits satisfaction. } \\
\text { Late: Current legislation } \\
\text { favors flexible options. High } \\
\text { flexibility is prevalent in the } \\
\text { field and uncertainty or } \\
\text { interconnectedness is high. }\end{array}$ & $\begin{array}{l}\text { Employees have high } \\
\text { degree of control over } \\
\text { critical resources. }\end{array}$ & $\begin{array}{l}\text { Outcome uncertainty } \\
\text { and monitoring costs } \\
\text { are high. }\end{array}$ & $\begin{array}{l}\text { Critical skills are } \\
\text { organization-specific and } \\
\text { productivity is difficulty to } \\
\text { monitor. }\end{array}$ \\
\hline Limitations & $\begin{array}{l}\text { Neglects the role of interest } \\
\text { and agency. } \\
\text { Focuses on conformity. }\end{array}$ & $\begin{array}{l}\text { Neglects the role of } \\
\text { agency and transaction } \\
\text { costs. } \\
\text { Offers limited } \\
\text { explanation of adoption } \\
\text { decisions. }\end{array}$ & $\begin{array}{l}\text { Neglects the social } \\
\text { context. } \\
\text { Offers limited } \\
\text { explanation of adoption } \\
\text { decisions. }\end{array}$ & $\begin{array}{l}\text { Neglects the social } \\
\text { context. } \\
\text { Offers limited explanation } \\
\text { of adoption decisions. }\end{array}$ \\
\hline
\end{tabular}




\section{Institutional Theory}

As noted in Table 2, the institutional perspective posits that organizations will adopt an innovation, even if technically inefficient, in order to gain legitimacy, and hence the resources necessary to ensure their survival (Meyer \& Rowan, 1977; DiMaggio \& Powell, 1983; Zucker, 1987). Practices may be adopted voluntarily, in response to pressures to conform to accepted standards of practice; or involuntarily, in response to coercion by powerful institutional forces that control critical resources (DiMaggio \& Powell, 1983; Scott, 1987; Tolbert \& Zucker, 1996).

Proponents of this theory distinguish between early, or pre-institutional, adopters, who introduce an innovation based on its capacity to improve organizational performance; and later adopters, who, when the practice has become semi- or fully institutionalized, are more likely to behave according to prevailing practice (DiMaggio \& Powell, 1983; Tolbert \& Zucker, 1996).

The capacity of the institutional model to help explain variation in organizational structures is supported by several studies, including several that examined innovative pay and benefit practices (see, e.g., Scott, 1987; Powell \& DiMaggio, 1991; Tolbert \& Zucker, 1996, for reviews of this literature). The theory has been used to explain organizations' family-friendly policies (Goodstein, 1994; Ingram \& Simons, 1995; Osterman, 1995); child care (Kossek, Dass \& DeMarr, 1994); executive compensation (Westphal \& Zajac, 1994); and the compensation of retail sales personnel (Eisenhardt, 1988). Nevertheless, institutional theory does not fully explain variations in these practices and structures. Critics note that it fails to take into account the importance of the organizations' strategic goals and self-interests (DiMaggio, 1988; Oliver, 1991). The institutional model seems to provide fuller explanations of organizational structures when integrated with other theories. Researchers have integrated the insights offered by the institutional model with those offered by resource dependence (Oliver, 1991; Goodstein, 1994; Ingram \& Simons, 1995), agency (Eisenhardt, 1988), and transaction cost (Pouder, 1996; Roberts \& Greenwood, 1997). We are aware of no research that has attempted a comprehensive integration of the unique insights offered by the four theories.

The resource dependence, agency and transaction cost perspectives all suggest that expectations about efficiency drive decisions about structures such as flexible benefit plans. Further, as Table 2 indicates, the models share some key variables and assumptions. Yet each focuses on different types of efficiency gains, thereby offering unique insights into the factors affecting management's decisions about flexible benefit plans. For the purposes of this article, we grouped the three theories into one category focusing on expected efficiency gains. 


\section{Expected Efficiency Gains}

Resource dependence theory. Table 2 notes that the resource dependence model assumes that management's decisions are heavily influenced by internal and external agents who control critical resources (Pfeffer \& Salancik, 1978). Internally, certain positions or employee groups that control critical resources can theoretically impose preferred structures on their organizations (Pfeffer \& Salancik, 1978). Balkin \& Bannister (1993) argued that employees holding critical jobs in an organization can influence decisions about forms of pay (salary, incentives, benefits, etc.). High pay and attractive benefits can also attract and retain individuals who have the greatest ability to obtain critical resources (Pfeffer \& Davis-Blake, 1987).

External agents may control funds (e.g., government contracting agencies) or personnel (e.g., unions), and can exert pressure on an organization to adopt certain structures by linking compliance with resource allocation (Pfeffer \& Salancik, 1978; Pfeffer, 1981). These external pressures bear a remarkable resemblance to the institutional model's "coercive pressures," and distinguishing between the two models' explanations of organizations' structures can therefore be difficult (Zucker, 1987; Tolbert \& Zucker, 1996). As Oliver (1991) and others point out, however, the resource dependence model views organizations as responding more strategically, or autonomously, to external pressures than does the institutional model. Hence, whereas both models consider external pressures, the resource dependence model also considers characteristics of the organizations that affect the extent to which decision-makers actively manage the pressures versus passively comply with them (Oliver, 1991; Greening \& Gray, 1994). Goodstein (1994) for example, found that resistance to pressures to adopt family-friendly policies varied with the percent of women in the organization's workforce.

Resource dependence-based explanations of organizational structures have generally been supported by empirical research. Pfeffer and Davis-Blake (1987) found that pay level decisions for employees occupying the same position in different organizations could be partially explained by differences in the role the position plays in the acquisition of monetary resources. As noted above, a number of studies have successfully integrated the resource dependence and institutional models to partially explain a variety of organizational practices, including benefits.

Agency theory. The focus of the agency model is on the design of optimal employment contracts. The model's premise is that the interests of principals may partially conflict with those of the agents, and that compensation packages should be designed to motivate employees to act in the best interests of the principal (Ross, 1973; Jensen \& Meckling, 1976). Outcome-based contracts provide powerful incentives for agents to be as productive as possible, but where outcomes are uncertain, agents will demand higher pay to offset attendant risk. Behavior-based 
contracts shift the risks to the presumably risk-neutral principal, but where information about agent effort is difficult to obtain, incentives for agents to work in the best interests of the principal are weak. Where outcome uncertainty is high, and monitoring employee productivity is difficult or costly, optimal contracts are more difficult to design. A possible solution to this dilemma is to pay so-called "efficiency wages," i.e. wages that are above the market-clearing rate (Nalbantian, 1987; Stiglitz, 1987). Paying these higher wages creates an incentive for employees to work at least hard enough to keep their jobs. At the same time, their pay is not dependent upon the outcomes of their efforts, which can be affected by factors other than employee effort.

We suggest that the agency and efficiency wage concept, which has most frequently been applied to issues of direct pay, can be extended to total compensation (pay plus benefits). Base pay and benefits that are not tied to performance are generally considered to have a weak or indirect impact on motivation (i.e., through promotions). This premise suggests that base pay and benefits are tied to continued employment, and if high enough will induce employees to work at least hard enough to keep their jobs (Shapiro \& Stiglitz, 1984). A similar argument is made by Shepard, Clifton and Kruse (1996), who applied the efficiency wage theory to explanations of decisions to adopt flexible work hours. The authors argued that employees who value flextime will prefer to work in organizations that provide it, and will work hard enough to keep such employment because the cost of being fired (and losing flextime) is high (Shepard et al., 1996).

A large body of research explores the implications of agency theory for employee compensation (see Eisenhardt, 1989 for a review). In general, these studies support the agency model. Once again, many of the studies use both agency and companion theories to examine research hypotheses, an approach supported by Eisenhardt (1989: 71), who argued that agency theory "presents a partial view of the world that," although valid, "also ignores a good bit of the complexity of organizations." Specifically, agency theory tends to over emphasize efficiency explanations of organizational structures and neglect the institutional context in which they are established (Kalleberg \& Reve, 1993; Nilakant \& Rao, 1994).

Transaction cost. This perspective assumes that organizations establish structures that minimize the costs of their transactions (the exchange of goods or services) with other parties when the potential for opportunistic behavior is high (Williamson, 1981). In the case of human resource transactions, the potential for opportunistic behavior is related to two important "human asset" characteristics: First, where critical skills specific to the organization are acquired primarily on the job, turnover can be costly, and internal governance structures are adopted to stabilize employment. Second, where individual productivity is difficult to monitor, governance structures are adopted to provide incentives for employees to act in the organization's interests (Williamson, 1981: 
564). To the extent that employees value flexible benefits, adopting the plans would increase the value of continued employment, hence reducing voluntary turnover and shirking.

Transaction cost explanations of organizational structures have for the most part been supported by research (see Klein \& Shelanski, 1994 for a review). Much of the work has focused on vertical integration, however the model has also been used to explain a variety of governance issues (Klein \& Shelanski, 1994). Williamson (1981) argued that transaction costs can also explain the adoption and design of specific human resource practices (such as flexible benefits), yet empirical evidence in this area is limited. One study found that the extent of transaction costs such as firm-specific training can help explain the adoption of contingent work arrangements (DavisBlake \& Uzzi, 1993). In response to criticism that the model neglects contextual variables such as power and institutional pressures, recent research has combined transaction cost explanations with other perspectives, most notably institutional theory (Pouder, 1996; Roberts \& Greenwood, 1997).

\section{Summary: Sources of Convergence and Divergence}

As Table 2 illustrates, there is both convergence and divergence in the insights offered by the individual theories. The potential for integrating the four theories without creating redundancy and incongruity may therefore seem limited. Yet a recurring theme in the empirical literature is that richer explanations of organizational structures can be derived by integrating the insights of multiple theoretical perspectives. Oliver (1991) argued that convergence demonstrates the potential for integrating complementary explanations of organizational structures into a single model. Further, divergence "highlights the underlying assumptions about organizational behavior" that are not acknowledged by a single theory and demonstrates the value of integrating multiple theories (Oliver, 1991: 146).

Whereas all four perspectives assume that management's decisions about structures are constrained by environmental conditions, they differ in their assumptions about the nature of those constraints. External pressures are assumed to be the primary source of influence on decisions under the institutional model, whereas internal conditions related to the nature of the work constitute the primary constraints under the agency and transaction cost models. The resource dependence model assumes that internal and external agents impose constraints on decisions about structures. Further, both the agency and transaction cost models assume that constraints arise as a result of goal conflict, information asymmetries, and the tendency of people to act in their own self-interest.

Differences in assumptions about organizations' responses to environmental constraints, as noted in Table 2, are perhaps the most striking. Organizational interest and agency are assumed to play an important role in determining these responses under the resource dependence, agency and transaction cost models. These "rational" models all assume that organizations actively manage 
environmental constraints, adopting structures that ensure the flow of resources, or minimize agency or transaction costs. Hence, the primary source of influence on management's decisions under these perspectives is what we refer to as expected efficiency gains. The institutional model, on the other hand, assumes that organizations do not exercise active choice; rather, they more passively conform to their environments. Organizations theoretically adopt structures that enhance their legitimacy in the external environment, regardless of the impact on the technical efficiency of internal operations. Thus, institutional pressures are the primary source of influence on management's decisions about structures such as flexible benefits.

We argue that the integration of the four theoretical perspectives is not only feasible but necessary to understand decisions about flexible benefit plans. All of the theories seem to offer insights, yet none offers a full explanation. Institutional theory has been criticized for ignoring the role of organizational interest and agency (DiMaggio, 1988; Oliver, 1991). The agency and transaction cost models, on the other hand, have been criticized for overemphasizing efficiency and ignoring social context variables (Eisenhardt, 1989; Kalleberg \& Reve, 1993; Nilakant \& Rao, 1994). Further, although the resource dependence, agency and transaction cost models all suggest that expected efficiency gains drive decisions, each focuses on different types of gains. In response to these criticisms, researchers have integrated different combinations of the theories. We are aware of no research that has attempted to integrate the unique and tenable insights of all four models. Accordingly, we take the logical next step and propose a model for explaining management's decisions about the adoption and design of flexible benefit plans that integrates the insights of the institutional, resource dependence, agency and transaction cost theories.

\section{AN INTEGRATED APPROACH TO EXPLAINING THE ADOPTION AND DESIGN OF FLEXIBLE BENEFITS}

As depicted in Figure 1, management's decisions about flexible benefits are hypothesized as primarily influenced by two factors: institutional pressures and expected efficiency gains. These two factors provide the framework for our discussion of the model. First, we examine the theoretical premises underlying each of the factors. We identify antecedent variables that are likely to shape the strength and direction of each factor's effects on management's decisions about the adoption and design of the plans, and develop testable propositions. Second, we examine variables that affect the relative strength of the two primary factors, again developing a set of related propositions. 


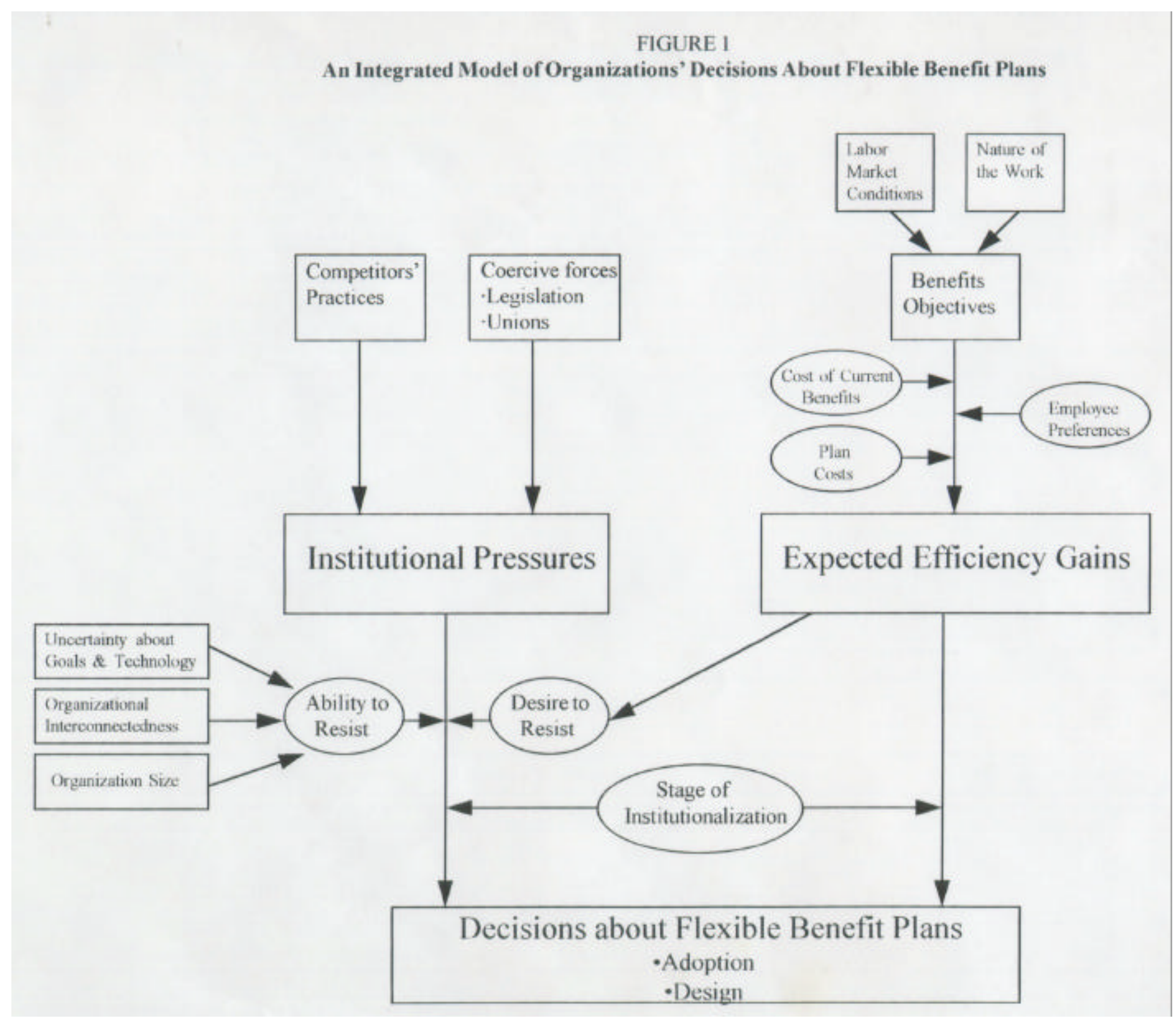




\section{Institutional Pressures}

The institutional model suggests that internal decisions about structures are heavily influenced by pressures in the external environment (Goodstein, 1994; Ingram \& Simons, 1995). Below we outline the ways in which institutional pressures to conform to practices such as flexible benefits are theoretically generated.

Antecedents of institutional pressures: Competitors' practices. As a practice becomes more diffused, it is increasingly viewed as standard, or best, practice, theoretically tying the organization's legitimacy and ability to obtain resources to compliance (Meyer \& Rowan, 1977; Tolbert \& Zucker, 1996). Hence, as the portion of competitors in an organization's field or industry adopting a flexible benefit plan, or a particular plan design, increases, the strength of the pressures to adopt the plan also increases. The pressures to adopt should be greater in the health care industry, for example, where over two-thirds of organizations offer flexible benefits, than in manufacturing, where the incidence is lower. Similarly, the pressures to include a flexible spending account in the plan should be highest in the services industry, where the incidence of the accounts is highest. Thus,

Proposition 1a: The rate of new flexible benefit plan adoptions will be higher in industries in which the portion of organizations offering the plans is high, than in industries in which the portion is low.

Proposition 1b: Organizations implementing a new flexible benefit plan are likely to match the plan design (e.g., Core + Optional Coverage or Mix and Match) most commonly used in their field or industry.

Antecedents of institutional pressures: Coercive forces. Institutional pressures that are more coercive in nature may be generated by external agents who control critical resources and have the power to impose preferred structures on an organization (DiMaggio \& Powell, 1983; Scott, 1987; Tolbert \& Zucker, 1996). Our model suggests that unions may exert such pressures. Powerful unions that control the supply of labor should theoretically be able to influence management's decisions about benefits practices. Unions tend to view flexible benefit plans with disfavor -- primarily because of the concomitant reductions in employer benefits that often occur, and because the resultant lack of uniformity in benefits is counter to the unions' egalitarian philosophy and makes contract negotiations more difficult (Mulcahy, 1990; Employee Benefit Research Institute, 1991; Wiatrowski, 1994). The resource dependence model suggests, however, that the strength of these pressures will depend on the importance of the resources and the extent to which they can be obtained from other sources (Pfeffer \& Salancik, 1978; Pfeffer, 1981; Meznar \& Nigh, 1995). Hence, coercive pressures are likely to be strongest in highly unionized and labor- 
intensive sectors, where human resources represent critical inputs to production and the power of unions to withhold or supply labor is high. Close to half of the workers in the labor-intensive public sector, for example, are union members, suggesting high union control over critical resources (Freeman, 1996). We predict that,

Proposition 2: The rate of new flexible benefit plan adoptions will be lower in highly unionized, labor-intensive organizations than in organizations where the degree of unionization is low.

Government agencies may also exert coercive pressure on organizations to adopt preferred structures (DiMaggio \& Powell, 1983). Restrictions on employee compensation, for example, can be imposed on organizations that have federal contracts. We are aware of no such contingencies related to flexible benefits. The government has, however, passed legislation over the past 20 years that has variously encouraged or discouraged adoption of the plans. Prior to 1978 , the federal tax code discouraged conventional flexible benefit plans, i.e. plans in which employees could choose between taxable and nontaxable benefits. The "doctrine of constructive receipt" essentially increased the costs of such plans by requiring that employees' taxable income be calculated as if they had received the maximum amount of taxable benefits available, regardless of their actual selections (Beam \& McFadden, 1996). The Revenue Act of 1978 ended the application of this doctrine to flexible benefit plans, thus restoring favorable tax treatment. Other laws, although not specifically addressed to flexible benefits, may have had the effect of pushing organizations to build more flexibility into their benefit plans. The Health Maintenance Act of 1973 required employers to give employees the option of joining a Health Maintenance Organization (HMO) if one were locally available (Beam \& McFadden, 1996). More recently, legislation requiring unpaid leave for family medical needs and portable health insurance has increased the pressure on employers to become more flexible. Hence, the strength of legal pressures to introduce flexibility into benefits programs seems to be increasing. ${ }^{2}$

Decisions about the design of flexible benefits may also be affected by coercive governmental pressures. Concerned about the potential loss of tax revenues resulting from pre-tax contributions to flexible spending accounts, the federal government established the "use it lose it rule" in 1984. The rule had the effect of limiting employee use of these accounts by requiring that any money left in the funds at the end of the enrollment period be forfeited. 1989 legislation further discouraged employers from offering flexible spending accounts by requiring them to make available at the beginning of the enrollment period the full amount of the yearly contribution election, even if employees had not yet made the full amount of the contributions to the account. 
Changes in legislative pressures are not necessarily related to changes in management's decisions about the adoption and design of flexible benefit plans. As Tolbert and Zucker (1983) pointed out, strong resistance can lead to noncompliance with unpopular legislation (e.g., mandated integration of public schools). Further, the resource dependence model suggests that, rather than passively conforming to such pressures, organizations will attempt to actively manage them wherever feasible and desirable (Oliver, 1991). Indeed, Section 89 of the Internal Revenue Code, which created complicated nondiscrimination rules for all employer benefit plans, was repealed just three years after its passage, following objections that the rules were too difficult and costly to implement (Employee Benefit Research Institute, 1991). Evidence suggests, however, that organizations have generally been responsive to changes in legislation pertaining to flexible benefits. In 1984, the year the federal government issued regulations clarifying the terms and restrictions on flexible benefit plans set out by section 125 of the Internal Revenue Code, new adoptions of the plans increased by $127 \%$. Based on theory and evidence then, we predict that,

Proposition 3a: The rate of increase in new adoptions of flexible plans will be highest around the introduction of favorable legislation.

Proposition 3b: The variety of plan designs will be responsive to favorable legislation.

\section{Expected Efficiency Gains}

Insights regarding the effects of efficiency concerns on decisions about flexible benefit plans are offered by all four theoretical perspectives. Under the institutional model efficiency is only expected to play an important role during the early, pre-institutionalization stage, when the incidence of the plans is low and adoption decisions "depend on the degree to which the change improves internal process" (Tolbert \& Zucker, 1983: 26). The resource dependence model implies that organizations adopt total compensation systems that will ensure the flow of critical resources (Pfeffer \& Davis-Blake, 1987; Balkin \& Bannister, 1993). The agency model suggests that organizations adopt compensation structures that will reduce shirking where productivity is difficult and/or costly to monitor (Eisenhardt, 1989). Under the transaction cost model, organizations theoretically use compensation systems both to reduce shirking where productivity is difficult to monitor and to reduce costly turnover among employees who have received firm-specific training (Williamson, 1981).

Antecedents of expected efficiency gains: Benefits objectives. The institutional perspective assumes that during the pre-institutionalization years of flexible benefit plan adoption, when external pressures are weak, management makes decisions about the plans based on their expected impact on technical operations. Hence, organizations would only be likely to adopt flexible plans during this stage if the promised outcomes (enhanced benefits satisfaction, cost 
containment) were (a) important to the effectiveness of the organization's benefits plan, and (b) likely to be achieved. Adoption decisions should therefore be determined, at least in part, by the organization's benefits objectives. Similarly, the particular type of design implemented should be logically related to the achievement of plan objectives. The assumption under the resource dependence, agency and transaction cost perspectives that organizational interest and agency play an important role in determining structures also implies that decisions about flexible plans will be rationally related to benefits objectives. Predicting decisions about the plans therefore requires information about organizations' benefits objectives.

Although the institutional model implies that decisions about flexible plans during the early stage will be influenced by benefits objectives, the model's focus is primarily on explaining environmental constraints on decisions during the later stages. Insights into the particular factors that constrain the setting of benefits objectives are more readily derived from the resource dependence, agency and transaction cost models. Together, these three perspectives suggest two sets of factors affecting organizations' benefits objectives: labor market conditions and the nature of the work.

Theoretically, the nature of the work affects the value of employees and the ease of monitoring their productivity. Under the resource dependence model, attributes of the work affect the extent to which organizations are dependent on employees for the acquisition and/or efficient use of critical resources (Bartol \& Martin, 1988). Where resource dependency is high, organizations will emphasize satisfaction objectives as a means of attracting and retaining critical employees (Pfeffer \& Davis-Blake, 1987; Balkin \& Bannister, 1993). Bartol and Martin (1988) identified four work attributes that affect employee control over critical resources: the degree of uncertainty surrounding the achievement of tasks, the importance of task achievement to the organization (task centrality), the ease with which the work can be observed and measured, and the level of skill specialization required to achieve tasks (Bartol \& Martin, 1988). Such conditions might be found in the research and development division of a high-tech company, where creative efforts related to product development can be difficult to monitor, specialized skills required to perform the work can be difficult to replace, and the development of innovative products is central to the company's success (Bartol \& Martin, 1988; Eisenhardt, 1989). We propose a fifth factor: the extent to which the technology is labor versus capital intensive. Where human resource inputs represent a relatively small part of the production process, operations can continue even when these inputs are withdrawn. Accordingly, capital-intensive organizations (e.g., oil, chemical), although dependent on workers with discretionary control over resources, are relatively less so than more labor-intensive organizations (e.g., service). ${ }^{3}$ 
The agency model implies that benefits satisfaction will take precedence over cost containment objectives where organizations face both high monitoring costs and high outcome uncertainty. Under these conditions, behavior-based contracts provide limited incentives for selfinterested agents to act on behalf of the principal, and outcome-based contracts inefficiently allocate risks to risk-averse agents. Alternatively, under a behavior-based/efficiency wage approach, compensation is tied not to outcomes but to continued employment, the desirability of which is increased by offering employees pay and benefits that they value (Nalbantian, 1987). Monitoring costs are reduced because employees do not want to risk losing their jobs (with the valued benefits) and therefore have an incentive not to shirk even when they are not being closely monitored (Calvo, 1987; Shepard, Clifton \& Kruse, 1996). Like the resource dependence model, then, the agency model implies that where employee effort is difficult or costly to monitor, organizations are likely to emphasize offering benefits systems that enhance employee satisfaction. A key variable not suggested by the resource dependence or other models is outcome uncertainty, i.e. the extent to which outcomes are affected by factors beyond employee effort and/or are difficult to measure. To illustrate, consider consulting firms, where professionals with specialized knowledge may be difficult to monitor, and outcomes are affected by factors beyond the consultant's control. When management in such organizations decides to implement flexible benefits, the aim is more likely to be enhancing employee satisfaction.

The ease of monitoring productivity emerges as a key work attribute explaining organizations' benefits objectives under the transaction cost model as well. When monitoring is difficult the potential for opportunistic behavior is high. The assumption is that employees are not apt to work hard if they believe that lower effort is unlikely to result in any negative consequences. Incentives for employees to act in the interests of the organization are in many cases provided by tying the employee's pay to organization or individual performance. Kalleberg and Reve (1993), however, argue that "in an economic sense, incentives are the price vector of the contract, and include pay, bonuses, and fringe benefits." As with the resource dependence and agency models, this implies that the "price" of employment, hence the cost of losing it, affects employees' propensity to act in the interest of the organization.

A second attribute of work under the transaction cost model, one not specified by other models, is the extent to which skills required to achieve the work are acquired on the job (human asset specificity). Where critical skills specific to the organization are acquired primarily on the job, costly investments in training can be lost if workers quit before the expected productivity gains are fully realized. Examples of such organizations might include consulting firms, law firms and financial brokerage firms, where revenue creation is linked to building relationships among clients. 
In these circumstances, internal governance structures will be efficient if they stabilize employment. Benefits that accrue with seniority, for example, would discourage quitting (Williamson, 1981). Indeed, many flexible plans include a provision that the allocation of credits for purchasing benefits will increase with seniority (Employee Benefit Research Institute, 1991). Compensation packages that include pay or benefits that exceed what employees could obtain elsewhere would also discourage quitting. Hence, where critical skills are firm-specific and/or monitoring performance is difficult, organizations may try to minimize their transaction costs by offering total compensation packages that enhance the value of continued employment, thereby discouraging quitting or shirking. In this case, benefits objectives would emphasize employee satisfaction.

Labor market conditions theoretically affect the extent to which an organization is dependent on external agents for critical human resources. As noted earlier, unions that control the supply of labor to an organization can directly influence decisions about flexible benefit plans. At the same time, non-unionized organizations in industries where membership is high might seek to avoid union involvement by emphasizing employee satisfaction objectives and reducing workers' felt need for collective representation. Hence, the percent of union members in an organization's labor market may help explain benefits objectives. Conditions in the labor market also determine the ease with which critical skills can be replaced. Replaceability, as indicated by such labor market conditions as unemployment rates, theoretically affects organizational dependence on employees' resources and hence the importance of satisfying benefits preferences (Bartol \& Martin, 1988).

To summarize, an organization's benefits objectives can be explained, at least in part, by a set of variables describing internal work attributes and external labor market conditions. Where the work is such that the opportunities for self-interested or opportunistic behavior are high, and/or employee control over critical resources is high, organizations will tend to emphasize benefits satisfaction over cost control. Satisfaction is also likely to be the primary objective where union involvement is high, and/or there is a shortage of critical skills in the labor market. Organizations facing relatively less pressure from these conditions are less likely to be concerned with providing a valuable benefits plan, and more likely to focus on cost containment objectives. ${ }^{4}$

Of course, not all organizations whose primary benefits objective is employee satisfaction are going to adopt flexible benefits. Evidence suggests that employees' reactions to the plans vary, perhaps because the enrollment procedures are seen by some as confusing and time-consuming (Kossek, 1989). Nor can organizations always expect to achieve cost containment objectives by adopting flexible benefit plans. The costs of implementing the plans can be high, and possibly outweigh potential cost savings. We posit that the effect of benefits objectives on decisions about 
flexible plan adoption will be moderated by current (non-flexible) benefit plan costs, flexible plan implementation and administration costs (plan costs) and employee preferences.

Organizations whose primary objective is cost control are unlikely to adopt flexible benefits if the administrative costs of the plans are high relative to the expected returns. Small organizations, and/or organizations without established information systems, would be less likely to have the resources to cost-effectively implement and manage flexible benefit plans than would larger organizations, particularly in the early years of adoption, when software packages simplifying program administration were not yet available (Lawler, 1981). On the other hand, organizations with generous benefits such as first-dollar medical coverage (i.e., no deductible or coinsurance) might expect to contain the rising costs of benefits by moving from a defined benefit to a defined contribution arrangement, as often occurs with the introduction of flexible benefit plans.

Proposition 4a: Among organizations whose primary benefits objective is cost control, the propensity to adopt flexible benefit plans will be positively related to the munificence of current (non-flexible) benefits.

Proposition 4b: Among organizations whose primary benefits objective is cost control, the propensity to adopt flexible benefit plans will be positively related to organizational resources (as indicated by size and current information systems).

Organizations may expect flexible plans to enhance benefits satisfaction when its workforce is highly diverse (in terms of gender, ethnicity, age). Whether these organizations actually enhance satisfaction by adopting flexible benefits is unclear. In a study of employees' reactions to the introduction of a flexible benefit plan, Barber et al. (1992: 59, 62) found no significant relationships between satisfaction with the plan and "divergence from the traditional profile" (i.e., "long-tenure, married males with children and nonworking spouses"). Nevertheless, survey evidence clearly suggests that employers believe that adopting flexible benefits will enhance the benefits satisfaction of a diverse workforce (Employee Benefit Research Institute, 1995; Hewitt, 1995). Organizations may also expect flexible benefit plans to increase the benefits satisfaction of employees who are relatively well educated if, as Lawler $(1981 ; 1990)$ has argued, such employees prefer to be involved in making decisions that affect them. It may also be that employees in the higher income tax brackets are attracted to flexible plans because of options (such as flexible spending accounts) that provide a tax shelter for cash earnings. Hence, we predict that,

Proposition 5: Among organizations whose primary benefit objective is employee satisfaction, the propensity to adopt a flexible benefit plan will be positively related to the diversity, education and income level of the work force. 
The assumption that expectations about efficiency gains drive decisions about flexible benefits implies the plans will be designed in accordance with benefits objectives. Thus, we would expect programs implemented primarily to meet the diverse benefits needs of a heterogeneous work force to offer more flexibility to employees in selecting their benefits. As Table 1 indicates, plan designs that provide the most choices, or flexibility, are the Core + Optional Coverage and Mix \& Match plans. Organizations emphasizing employee satisfaction are more likely to implement these plan designs rather than the Modular Options plan, which limits choices to pre-packaged plans, or the Salary-Reduction-Only plan, which simply offers the opportunity to pay for predetermined benefits with pre-tax dollars. Therefore, we predict that

Proposition 6: Organizations whose primary benefit objective at the time of flexible benefit plan adoption is employee satisfaction are more likely to offer the Core + Optional Coverage or Mix and Match plan, than are organizations that emphasize cost control.

Organizations emphasizing cost containment objectives, on the other hand, are unlikely to offer a lot of choices. Administrative costs could be minimized by offering the Salary-ReductionOnly or Modular Options plans, which offer less flexibility and are therefore less costly to implement, communicate and manage (Beam \& McFadden, 1996). These organizations might also be less likely to offer flexible spending accounts, because allowing employees to pay insurance premiums and uncovered medical expenses with pre-tax dollars essentially reduces the cost to workers of medical care and hence their incentive to use it carefully. Hence,

Proposition 7: Organizations whose primary benefit objective at the time of flexible benefit plan adoption is cost control are more likely to offer the Modular Options or SalaryReduction-Only plan, than are organizations that emphasize employee satisfaction.

\section{The Relative Strength of Institutional Pressures and Expected Efficiency Gains}

Although institutional and "efficiency" perspectives offer complementary rationales for decisions about flexible benefit plans, these two factors may also generate conflicting pressures on managers. According to the institutional view, organizations may often adopt structures that do not improve efficiency but do conform to prevailing practice (Tolbert \& Zucker, 1996). We suggest that the relative strength of the two factors will depend on three conditions: (1) The stage of institutionalization of flexible practices affects the strength of institutional pressures. During the preinstitutionalization stage, when few organizations have adopted these plans, pressures to adopt and design in specific ways are weak. Hence, these decisions depend on economic and technical issues. As more organizations adopt, the pressures to conform to prevailing practices become stronger. According to this logic, the economic efficiency rationales become less important or are maybe assumed by managers (If these leading companies are doing it, so should I). (2) 
Organizations may vary in their desire to resist the pressures. That is, if flexible benefit plans are expected to generate minimal, or negative, efficiency gains, managers may decide they should try to resist any pressures to adopt or design in a certain way (Oliver, 1991). Where the plans are too costly, and the organization is trying to contain costs, or unappealing to employees, and the organization is trying to enhance benefits objectives, the desire to resist is likely to be high. (3) Organizations vary in their ability to resist institutional pressures. According to institutional and resource dependence theorists, differences in ability to resist are related to differences in organizational interconnectedness, uncertainty about goals or technology, and organizational size (Greening \& Gray, 1994). Interconnectedness, also referred to as professionalization of managerial staff, is "the density of interorganizational relations among occupants of an organizational field" (Oliver, 1991: 171) The idea is that organizations managed primarily by professionals, or others belonging to interorganizational groups, will be heavily influenced by standard-setting academic institutions or professional networks, and will therefore tend to adopt the prevailing human resource practices in their field. In these circumstances, the collective strength of the pressures make them more difficult to resist (Oliver, 1991). Interconnectedness is likely to be observed in industries that have a lot of business, trade or professional organizations (Goodstein, 1994; Ingram \& Simons, 1995), such as service (consulting, health care, etc.) and high technology. Professional organizations such as the American Compensation Association, or the Society of Human Resource Management, tend to emphasize "leading edge" practices. Benchmarking other organizations' "best" practices is another example of how interconnectedness is manifested in practice. Uncertainty about goals or technologies theoretically induces organizations to imitate the practices of other organizations that are perceived as successful (DiMaggio \& Powell, 1983; Zucker, 1987; Oliver, 1991). Organizations in high-technology industries, or health care, for example, often operate in highly uncertain environments. Finally, the scale and resources of an organization, and hence its ability to resist institutional pressures, are related to its size (Pfeffer \& Salancik, 1978; Greening \& Gray, 1994). We therefore predict that

Proposition 8: The relationship between efficiency-related factors (benefits objectives, labor market conditions, nature of the work, current benefits costs, flexible plan costs, and employee preferences) and management's decisions about flexible plans will be stronger during the pre-institutionalization than the semi- and full-institutionalization stages.

Proposition 9: The relationship between institutional pressures and management's flexible benefit decisions will be stronger when conformity with the pressures (e.g., to adopt flexible benefits) does not conflict with cost containment or benefits satisfaction objectives. 
Proposition 10: The relationship between institutional pressures and management's flexible benefit decisions will be stronger among small organizations, or organizations where uncertainty or interconnectedness is high.

\section{IMPLICATIONS AND CONCLUSIONS}

Our purpose was to analyze and integrate four theoretical explanations of why organizations adopt flexible benefits and why such variety in plan designs exists. We generalized the theories into two primary foci -- institutional pressures and expected efficiency gains -- that influence both adoption and design decisions. As our integrated model demonstrates, further analysis of these decisions through the four theoretic lenses suggests sets of specific variables that must be included when studying management's flexible benefit decisions. Institutional pressures are contingent upon competitors' pressures and coercive forces such as legislation and unions. The expected efficiency gains are a function of plan objectives, which are in turn affected by labor market conditions, the nature of the work, employee preferences, and costs. The relative strength of institutional versus efficiency factors is moderated by the stage of institutionalization, as well as factors related to the organization's resistance to institutional pressures.

\section{Application to Other Human Resource Innovations}

Generalizing the insights gained from exploring a specific HR innovation -- flexible benefits -to questions surrounding decisions about other innovations remains to be demonstrated. We believe that our analysis of the four theories and related research provides a useful framework for such efforts. Further, we submit that our integrated model offers insights into the decisions management makes about other HR innovations. Our model may have limited generalizability when it comes to some of the moderating factors such as workforce diversity, which may be unique to flexible benefits, however even these variables offer a platform for future work.

Consider the case of self-managed work teams. Our model implies that explanations for observed patterns of team implementations must include an examination of the institutional pressures related to teams. Considering first competitors' practices, we find that adoptions of this innovative practice have in recent years increased substantially among manufacturing firms (Osterman, 1994; Banker, Field, Schroeder \& Sinha, 1996; Cohen, Ledford \& Spreitzer, 1996). This trend suggests that competitors' practices in the manufacturing sector will generate strong institutional pressures favoring the adoption of the team approach. Hence, new team implementations are likely to be higher in this sector than in other sectors where the approach is less prevalent. At the same time, many unions oppose the adoption of teams, which they view as undermining the role of unions in representing workers (Kochan, Katz \& McKersie, 1994). The National Labor Relations Act, which prohibits organizations from forming company unions, has 
recently been invoked by the National Labor Relations Board (NLRB) to bar certain types of teams in nonunion settings (Flynn, 1996). Consequently, in settings that are currently unionized and/or in settings where unions are attempting to organize workers, coercive legislative and union forces generate institutional pressures on organizations not to adopt a team approach. Variability in the strength of these pressures may help explain adoption patterns over time. Soon after the NLRB issued its first ruling against the use of teams, many organizations backed away from employee involvement initiatives or modified existing teams to be in compliance with the ruling (Flynn, 1996). However, a bill recently introduced in the U.S. Congress loosens the restrictions on teams (the Teamwork for Employees and Managers Act), reflecting a current political climate that favors the use of innovative approaches to work design (DeWine, 1997).

Decisions about structures such as teams will also, according to our model, be influenced by the efficiency gains organizations can expect to realize by adopting them. Indeed, survey evidence indicates that organizations implementing teams do so in the hopes of achieving gains in productivity, quality, costs, and employee satisfaction (Lawler, Mohrman \& Ledford, 1992). A key determinant of expected efficiency gains in the case of flexible benefit plans is benefits objectives. This factor is clearly not relevant to decisions about teams, however a closely related factor -human resource objectives -- might prove a useful substitute. Whether the primary objective in implementing teams is reducing production costs or enhancing employee satisfaction will in turn be influenced by the nature of the work and labor market conditions, as posited in our discussion (above) of the model. Organizations that depend on employees with specialized skills that are in short supply in the labor market, for example, would tend to emphasize employee satisfaction.

As our integrated model suggests, the impact of objectives on organizations' expectations about efficiency gains will depend on moderating factors. In the case of flexible benefits, these include costs and employee preferences. Employee preferences for flexible benefits are theoretically related to workforce diversity and education. Employee preferences will also affect the capacity of teams to achieve objectives, however the literature suggests a different set of indicators. Hackman and Oldham (1980) suggest that a team design will not lead to performance and satisfaction improvements if workers do not have a strong growth need. Lawler (1986) argues that needs for growth, achievement, competence, and social interaction are important. Contextual factors will also affect the extent to which teams can be expected to help achieve human resource objectives. Specifically, teams may be most successful in contexts where production tasks are interdependent and/or in "greenfield" sites (Lawler, 1986; Campion, Medsker \& Higgs, 1993).

As with flexible benefits, the relative influence of institutional pressures versus expected efficiency gains on management's decisions about teams will depend on the stage of 
institutionalization as well as the organization's ability and/or desire to resist institutional pressures. Factors related to the efficiency gains organizations can expect to achieve by adopting teams will exert more of an influence during the pre-institutionalization stage. During the semi- and fullinstitutionalization stages, organizational uncertainty, interconnectedness and size will affect the ability to resist pressures to adopt (or not adopt) teams. Finally, the desire to resist these pressures in the later stages of institutionalization will depend on whether the adoption of teams is consistent with the organization's objectives. Organizations with a long tradition of individual-based work have found that the introduction of teams can lead to employee discontent, making the achievement of employee satisfaction objectives difficult (Lawler, 1986).

The discussion above suggests that many of the factors posited to affect decisions about flexible benefit plans can also be applied to decisions about other HR innovations. The applicability of institutional pressures, expected efficiency gains, labor market conditions, employee preferences, and the nature of the work appears to go beyond the specific case of flexible benefits. Other factors may vary somewhat across contexts. Benefits objectives are only an appropriate factor when considering benefits innovations. Nonetheless, there are a number of such innovations for which this factor is appropriate, for example work-family benefits, or wellness programs. Further, we suggest that a closely related factor -- human resource objectives -- can be easily substituted into the model. Although we suggest that employee preferences moderate the effect of objectives on expected efficiency gains, we also argue that the relevant indicators of preferences vary across innovations. Finally, it may be appropriate to consider moderators other than costs and employee preferences when explaining other types of innovative practices (e.g., employees' growth needs in the case of teams).

\section{Implications for Theory and Research}

The integrated model we propose represents the first attempt that we can find at synthesizing the implications of these four leading theories for decisions about organization structures. As we noted, others have integrated two theories (e.g., institutional and resource dependence, institutional and agency), but ours is the first to draw insights from all four. Arguably, integrating four theories to better understand organizational behavior yields a more parsimonious model. Empirical studies of our model will provide tests of its efficacy in explaining management decisions about flexible benefits. As we noted, very little is known about flexible benefit decisions at the organizational level of analysis. Our intent is to support organization scholars in the use of multiple theories in their study of employee benefits and, by implication, other HR innovations.

We should note that many of the explanatory factors included in our model may be endogenous. For example, the model implies that workforce diversity is a determinant of the 
decision to adoption flexible plans. But it may also be true that the presence of flexible plans affects the diversity of workers who seek employment at an organization. Similarly, the resource dependence, agency and transaction cost models all suggest that inadequate information about work effort will cause organizations to increase the value of their total compensation packages. At the same time, the level of overall compensation may influence employees' willingness to share information about their work effort. Empirically sound tests of the model may therefore require the estimation of simultaneous equations.

\section{Implications for Practice}

Although our purposes did not include an applied focus, we believe that managers may also gain insight from our model and analysis. The model clearly delineates the principal factors that leading theories specify influence whether and why types of flexible plans are adopted. It focuses managers' attention on both institutional reasons (based on benchmarking, following competitors, regulatory pressures) as well as expected economic gains. Experience suggests that although the rhetoric around adopting many HR innovations is expressed in terms of expected economic gains, the reality may be that government regulations as well as fads and fashions prevail (Dyer \& Reeves, 1995). Our model calls out for the first time, in one integrated guide, very specific factors managers could consider when faced with decisions about whether or not to adopt flexible plans or what type of plan design to implement (Rosenbloom, 1996). 


\section{ENDNOTES}

${ }^{1}$ When referring to decisions to adopt and design flexible plans we mean those organizational decisions made by top-level management. For simplicity we use the term "management's decisions" in the article.

${ }^{2}$ Many of the ideas about the effects of governmental legislation are based on comments from an anonymous reviewer.

${ }^{3}$ Industry examples such as these are used for the purpose of illustration only. Empirical tests of our model would require direct measurement of variables such as task uncertainty rather than the use of proxies such as industry.

${ }^{4}$ Obviously, organizations typically claim multiple benefits objectives, which include both employee satisfaction and cost containment (Beam \& McFadden, 1996). Nevertheless, survey evidence suggests that organizations prioritize their objectives and easily specify a single, primary objective behind their decisions to adopt practices such as flexible plans. In a 1992 survey, $52 \%$ of the participating firms indicated their primary reason for implementing flexible benefits was health benefits cost containment, and $28 \%$ indicated the primary objective was to satisfy diverse employee needs (Employee Benefit Research Institute, 1995). Our analysis suggests that the primary objective will be more helpful than secondary objectives in explaining management's decisions about flexible benefit plans. 


\section{REFERENCES}

Balkin, D.B. \& Bannister, B.D. 1993. Explaining pay forms for strategic employee groups in organizations: A resource dependence perspective. Journal of Occupational and Organizational Psychology, 66: 139-151.

Banker, R.D., Field, J.M., Schroeder, R.G. \& Sinha, K.K. 1996. Impact of work teams on manufacturing performance: A longitudinal field study. Academy of Management Journal, 39: 867-890.

Barringer, M.W. \& Milkovich, G.T. 1996. Employee health insurance decisions in a flexible benefits environment. Human Resource Management, 35: 293-315.

Barringer, M.W. \& Mitchell, O.S. 1994. Workers' preferences among company-provided health insurance plans. Industrial \& Labor Relations Review, 48: 141-152.

Bartol, K. M. \& Martin, D. C. 1988. Influences on managerial pay allocations: A dependency perspective. Personnel Psychology, 41: 361-378.

Beam, B.T. \& McFadden, J.J. 1996. Employee benefits. Chicago, IL: Dearborn Financial Publishing, Inc.

Bloom, D. E. \& Trahan, J. T. 1986. Flexible benefits and employee choice: Highlights of the literature. New York: Pergamon Press.

Borleis, M.W. 1996. Cafeteria plans in operation. In J.S. Rosenbloom (Ed.), The handbook of employee benefits: 505-540. Chicago: Irwin.

Cable, D.M. \& Judge, T.A. 1994. Pay preferences and job search decisions: A personorganization fit perspective. Personnel Psychology, 47: 317-348.

Calvo, G.A. 1987. The economics of supervision. In H. R. Nalbantian (Ed.), Incentives, cooperation, and risk sharing: 3-43. Totowa, NJ: Rowman and Littlefield.

Campion, M.A., Medsker, G.J. \& Higgs, A.C. 1993. Relations between work group characteristics and effectiveness: Implications for designing effective work groups. Personnel Psychology, 46: 823-850.

Cohen, S.G., Ledford, G.E. Jr. \& Spreitzer, G.M. 1996. A predictive model of self-managing work team effectiveness. Human Relations, 49: 643-676.

Davis-Blake, A. \& Uzzi, B. 1993. Determinants of employment externalization: A study of temporary workers and independent contractors. Administrative Science Quarterly, 38: 195223.

DeWine, M. 1997. Roll Call, June 16.

DiMaggio, P. 1988. Interest and agency in institutional theory. In Zucker, L.G. (Ed.), Institutional patterns and organizations: Culture and environment. Cambridge, MA: Ballinger. 
DiMaggio, P.J. \& Powell, W.W. 1983. The iron cage revisited: Institutional isomorphism and collective rationality in organizational fields. American Sociological Review, 48: 147-160.

Dyer, L. \& Reeves, T. 1995. HR strategies and firm performance: What do we know and where do we need to go? International Journal of Human Resource Management, 6: 656-670.

Eisenhardt, K.M. 1988. Agency- and institutional-theory explanations: The case of retail sales compensation. Academy of Management Journal, 31: 488-511.

Eisenhardt, K.M. 1989. Agency theory: An assessment and review. Academy of Management Review, 14: 57-74.

Employee Benefit Research Institute. 1991. Flexible benefits plans and changing demographics. EBRI Issue Brief, 113.

Employee Benefit Research Institute. 1995. EBRI databook on employee benefits. Washington, D.C.: Employee Benefit Research Institute.

Flynn, G. 1996. TEAM Act: What it is and what it can do for you. Personnel Journal, 75: 85-87.

Freeman, R.B. 1996. Through public eyes: Employee attitudes toward public sector labor relations in the U.S. In D. Belman, M. Gunderson, \& D. Hyatt (Eds.), Public sector employment in a time of transition: 59-83. Madison, WI: Industrial Relations Research Association.

Goodstein, J.D. 1994. Institutional pressures and strategic responsiveness: Employer involvement in work-family issues. Academy of Management Journal, 37: 350-382.

Greening, D.W. \& Gray, B.G. 1994. Testing a model of organizational response to social and political issues. Academy of Management Journal, 37: 467-498.

Hackman, J.R. \& Oldham, G.R. 1980. Work redesign. Reading, MA: Addison-Wesley.

Heshizer, B. 1994. The impact of flexible benefits on job satisfaction and turnover intentions. Benefits Quarterly, 4: 84-90.

Hewitt Associates. 1995. Flexible compensation programs and practices: 1994-95. Lincolnshire, IL: Hewitt.

Ingram, P. \& Simons, T. 1995. Institutional and resource dependence determinants of responsiveness to work-family issues. Academy of Management Journal, 38: 1466-1482.

Jensen, M.C. \& Meckling, W.H. 1976. Theory of the firm: Managerial behavior, agency costs and ownership structure. Journal of Financial Economics, 3: 305-360.

Kalleberg, A.L. \& Reve, T. 1993. Contracts and commitment: Economic and sociological perspectives on employment relations. Human Relations, 46: 1103-1132.

Klein, P.G. \& Shelanski, H.A. 1994. Empirical research in transaction cost economics: A survey and assessment. Business and Public Policy Working Paper BPP-60, Center for Research in Management, Haas School of Business, University of California, Berkeley. 
Kochan, T.A., Katz, H.C. \& McKersie, R.B. 1994. The transformation of American industrial relations. Ithaca, NY: ILR Press.

Kossek, E.E. 1989. The acceptance of human resource innovation by multiple constituencies. Personnel Psychology, 42: 263-281.

Lawler, E.E., III. 1971. Pay and organizational effectiveness. New York: McGraw-Hill.

Lawler, E.E., III. 1981. Pay and organizational development. Reading, MA: Addison-Wesley.

Lawler, E.E., III.. 1986. High involvement management. San Francisco: Jossey-Bass.

Lawler, E.E. III, Mohrman, S. \& Ledford, G. 1992. Employee involvement and total quality management: Practices and results in Fortune 1000 companies. San Francisco: JosseyBass.

Meyer, J. W. \& Rowan, B. 1977. Institutional organizations: formal structure as myth and ceremony. American Journal of Sociology, 83: 340-363.

Meznar, M.B. \& Nigh, D. 1995. Buffer or bridge? Environmental and organizational determinants of public affairs activities in American firms. Academy of Management Journal, 38: 975-996.

Mulcahy, C. 1990. New workers said to spur flexible benefits. National Underwriter, 94: 37.

Nalbantian, H. R. 1987. Incentive compensation in perspective. In H. R. Nalbantian (Ed.), Incentives, cooperation, and risk sharing: 3-43. Totowa, NJ: Rowman and Littlefield.

Nilakant, V. \& Rao, H. 1994. Agency theory and uncertainty in organizations: An evaluation. Organization Studies, 15: 649-672.

Oliver, C. 1991. Strategic responses to institutional processes. Academy of Management Review, 16: $145-179$.

Osterman, P. 1994. How common is workplace transformation and who adopts it? Industrial and Labor Relations Review, 47: 173-188.

Osterman, P. 1995. Work/family programs and the employment relationship. Administrative Science Quarterly, 40: 681-700.

Pfeffer, J. 1981. Power in organizations. Boston: Pitman Publishing, Inc.

Pfeffer, J. \& Davis-Blake, A. 1987. Understanding organizational wage structures: A resource dependence approach. Academy of Management Journal, 30: 437-455.

Pfeffer, J. \& Salancik, G.R. 1978. The external control of organizations: A resource dependence perspective. New York: Harper \& Row.

Pouder, R.W. 1996. Privatizing services in local government: An empirical assessment of efficiency and institutional explanations. Public Administration Quarterly, 20: 103-126. 
Powell, W.W. \& DiMaggio, P.J. 1991. The new institutionalism in organization analysis. Chicago: University of Chicago Press.

Roberts, P.W. \& Greenwood, R. 1997. Integrating transaction cost and institutional theories: Toward a constrained-efficiency framework for understanding organizational design adoption.

Ross, S.A. 1973. The economic theory of agency: The principal's problem. American Economic Review, 63: 135-139.

Scott, W.R. 1987. The adolescence of institutional theory. Administrative Science Quarterly, 32 : 493-511.

Shapiro, C. \& Stiglitz, J. 1984. Equilibrium unemployment as a worker discipline device. American Economic Review, 74: 433-444.

Shepard, E.M. III, Clifton, T.J. \& Kruse, D. 1996. Flexible work hours and productivity: Some evidence from the pharmaceutical industry. Industrial Relations.

Stiglitz, J. E. 1987. The design of labor contracts: The economics of incentives and risk sharing. In H. R. Nalbantian (Ed.), Incentives, cooperation, and risk sharing: 47-68. Totowa, NJ: Rowman and Littlefield.

Tolbert, P. S. \& Zucker, L. G. 1983. Institutional sources of change in the formal structure of organizations: The diffusion of civil service reform, 1880-1935. Administrative Science Quarterly, 28: 22-39.

Tolbert, P.S. \& Zucker, L.G. 1996. Institutional analyses of organizations: Legitimate but not institutionalized. In S. Clegg, C. Hardy, W. Nord (Eds.), Handbook of organization studies. London: Sage Publications.

Westphal, J.D. \& Zajac, E.J. 1994. Substance and symbolism in CEO's long-term incentive plans. Administrative Science Quarterly, 39: 367-390.

Wiatrowski, W.J. 1994. Employee benefits for union and nonunion workers. Monthly Labor Review, 117: 34-37.

Williamson, O. E. 1981. The economics of organization: The transaction cost approach. American Journal of Sociology, 87: 548-577.

Zucker, L. G. 1987. Institutional theories of organization. Annual Review of Sociology, 13: 443464. 